\title{
Antimicrobial activity of Agaricus brasiliensis on Plasmopara viticola and its effect on the induction of resistance to the control of downy mildew on 'Isabel Precoce'
}

\author{
Atividade antimicrobiana de Agaricus brasiliensis sobre \\ Plasmopara viticola e seu efeito na indução de resistência \\ para o controle de míldio em videiras Isabel Precoce
}

\author{
Carla Garcia' *, Cacilda Márcia Duarte Rios Faria', Herta Stutz Dalla Santa', Renato Vasconcelos Botelho', \\ Aline José Maia'
}

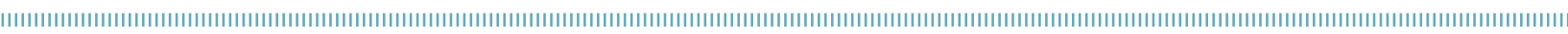

\begin{abstract}
Agaricus brasiliensis include bioactive compounds that can act as antibiotics, bacteriostatic, fungistatic and nematostatic substances. In this sense, this study aimed to evaluate the effect of a single application of aqueous mycelial suspension (AMS) of $A$. brasiliensis in control of downy mildew (Plasmopara viticola) and resistance induction in 'Isabel Precoce' grapevines under greenhouse conditions. Treatments consisted of three doses of $1 \%, 5 \%, 10 \%, 15 \%$ and $20 \%$ AMS A. brasiliensis, as well as treatment with acibenzolar-S-methyl (ASM). The variables analyzed were: sporangiospore germination, disease severity, represented by the area under the disease progress curve (AUDPC), catalase enzyme activity, peroxidase and polyphenol. The 10\%, 15\% and 20\% doses of AMS caused approximately $80 \%$ reduction in germination of $P$. viticola sporangiospores. The treatments did not show significant effects in reducing both the AUDPC of mildew and polyphenol oxidase enzyme activity. The A. brasiliensis aqueous mycelial suspension showed a fungitoxic effect on the germination of sporangiopores; however, it was not enough to reduce the severity of mildew in the 'Isabel Precoce' grapevines, even when acting on the catalase and peroxidase enzymes. Thus, experiments should be performed to verify the viability of the reproductive structures of the pathogen externalized in the vines when treated with $A$. brasiliensis AMS.
\end{abstract}

KEYWORDS: Plasmopara viticola; Vitis labrusca; aqueous mycelial suspension; elicitor.
RESUMO: Agaricus brasiliensis possui compostos bioativos que apresentam atividade antimicrobiana e induz mecanismos de defesa em plantas contra patógenos. O objetivo deste trabalho foi avaliar a aplicaçáo da suspensáo miceliada aquosa de $A$. brasiliensis no controle do míldio (Plasmopara viticola) e indução de resistência em videiras Isabel Precoce. Os tratamentos foram: 0, 1, 5, 10, 15 e 20\% da suspensão miceliada aquosa de $A$. brasiliensis, além do tratamento com acibenzolar-S-metil. As variáveis analisadas foram: germinação de esporangiósporos; severidade da doença, representada pela área abaixo da curva de progresso da doença; atividade da enzima catalase; peroxidase e polifenoloxidase. As doses 10, 15 e 20\% de suspensão miceliada aquosa de $A$. brasiliensis proporcionaram redução de aproximadamente $80 \%$ na germinaçáo dos esporangiósporos de P. viticola. Os tratamentos não apresentaram efeitos significativos na redução da área abaixo da curva de progresso da doença do míldio e na atividade da enzima polifenoloxidase. A dose de $10 \%$ da suspensão miceliada aquosa de $A$. brasiliensis reduziu a atividade de catalase e induziu a atividade da peroxidase. A suspensão miceliada aquosa de $A$. brasiliensis apresentou efeito fungitóxico na germinação de esporangióporos, entretanto não foi suficiente para reduzir a severidade do míldio da videira Isabel Precoce, mesmo atuando na atividade das enzimas catalase e peroxidase. Assim, experimentos deverão ser realizados para verificar a viabilidade das estruturas reprodutivas do patógeno exteriorizadas nas videiras quando tratadas com suspensão miceliada aquosa de $A$. brasiliensis.

PALAVRAS-CHAVE: Plasmopara viticola; Vitis labrusca; suspensão miceliada aquosa; elicitor. 


\section{INTRODUCTION}

The Brazilian wine sector is noteworthy for destining its final product for the production of table wines and juices. Among the cultivars used for this production, the rustic and fertile ink grape 'Isabel Precoce' stands out with its short cycle (CAMARGO et al., 2010).

However, this culture has some limitations that influences the yield and quality of the grapes produced, as is the case of diseases caused by phytopathogens. Among these diseases is mildew (Plasmopara viticola (Berk. \& M.A. Curtis) Berl. \& De Toni), which mainly affects the leaves, reducing the active photosynthetic area, thus causing losses in the vine production (JERMINI et al., 2010).

Pesticides are used to control this disease, which leads to several environmental impacts and selection of resistant strains. As a way to eliminate or at least reduce these problems, production technologies that are less aggressive to man and the environment are sought, such as active compounds present in mushrooms, which are able to induce resistance against phytopathogens in plants (SCHWAN-ESTRADA et al., 2012).

Among the mushrooms used as resistance inducers is Agaricus brasiliensis (Synonymy: A. blazei or A. subrufescens), which has bioactive compounds that can act as antibiotics, bacteriostatic, fungistatic and nematostatic substances (SCHWAN-ESTRADA et al., 2012). FIORI-TUTIDA et al. (2007) found that the A. blazei and Lentinula edodes mushrooms have a fungitoxic effect on the germination of Puccinia recondita f.sp. tritici spores. ARRUDA et al. (2012) also point out that aqueous extracts of $A$. blazei at a $10 \%$ dose induced the accumulation of phytoalexin gliceolin in 'CB202' soybean cotyledons.

In this context, this study aims to verify the effect of a single application of the aqueous mycelial suspension (AMS) from the $A$. brasiliensis mushroom in the control of mildew and in the induction of resistance on 'Isabel Precoce' grapevines.

\section{MATERIALS AND METHODS}

\section{Obtainment, maintenance and preparation of the}

\section{A. brasiliensis inoculum}

The $A$. brasiliensis mushroom from the fungi collection of the Bioprocesses Laboratory, Food Engineering Department, Universidade Estadual do Centro Oeste (UNICENTRO), was isolated from the fruiting body of a commercial culture. The inoculum was collected in an Erlenmeyers flask, and the methodology proposed by DALLA SANTA et al. (2009) was followed for its mycelial production.
To obtain the aqueous mycelial suspension (AMS) of A. brasiliensis, the mycelium ( $94 \%$ moisture) was thawed and weighed according to the dose determined for the experiments, and then macerated into a mortar. Subsequently, distilled water was added and the substance was triturated in a blender for two minutes.

\section{Evaluation of in vitro germination of $P$. viticola sporangiospores}

A volume of $100 \mathrm{~mL}$ of sterile distilled water containing $20 \mu \mathrm{L}$ of Tween 80 were added on vine leaves with typical symptoms of mildew, which were collected in the UNICENTRO orchard and, with a Drigalski handle, a smear was made on the pathogen's mycelium, which consequently caused the sporangiospores to be released. This suspension was standardized at $1 \times 10^{6}$ sporangiospores $\mathrm{mL}^{-1}$ with a Neubauer chamber count (hemocytometer).

The treatments tested in the germination control of these sporangiospores were $1 \%, 5 \%, 10 \%, 15 \%$ and $20 \%$ doses of A. brasiliensis AMS; acibenzolar-S-methyl (ASM) $(0.005 \%$ diluted in water) as standard treatment; and an absolute control (water only). Aliquots of $40 \mu \mathrm{L}$ of the pathogen suspension and another of $40 \mu \mathrm{L}$ of the double-dose treatments (due to dose dilution occuring in the presence of the pathogen suspension) were placed in individual wells of ELISA test plates.

The plates were then kept in a growth chamber at $25^{\circ} \mathrm{C}$ in the dark, each corresponding to a period $(4,6,12$ and 24 hours). In order to stop sporangiospore germination, $20 \mu \mathrm{L}$ of lactophenol cotton blue dye was added to each well at the time scheduled for evaluation. Subsequently, the percentage of germinated sporangiospores was evaluated at random in an inverted microscope, totaling 100 sporangia, in four replicates. Those that showed release of zoospores were germinated. The experimental design was completely randomized, with seven treatments and five replications.

\section{Effect of aqueous mycelial suspension on downy mildew control used on 'Isabel Precoce' grapevines under greenhouse conditions}

'Isabel Precoce' vine seedlings grafted on 'Paulsen 1103' rootstocks were planted on 01/23/2013 in $1 \mathrm{~L}$ pots containing Plantmax $^{\oplus}$ commercial substrate, and kept in a greenhouse for two cycles in the year 2013 .

The experimental design was in randomized blocks, with seven treatments and six replicates, and experimental plot constituted by one plant. When the seedlings presented eight leaves, the treatments were applied $(02 / 08 / 2013$ for the first cycle, and 11/04/2013 for the second cycle) with a hand sprayer, to the point of drainage, with $1 \%, 5 \%$, 
$10 \%, 15 \%$, and $20 \%$ doses of $A$. brasiliensis AMS (doses corresponding to a dry weight content of $0.06 \%, 0.3 \%$, $0.6 \%, 0.9 \%$, and $1.2 \%$ A. brasiliensis), plus a treatment with the commercial resistance inducer $0.005 \%$ acibenzolar-S-methyl (ASM), and control (no treatment). After $24 \mathrm{~h}$ of the applications, the pathogen was inoculated with suspension of $1 \times 104$ sporangiospores $\mathrm{mL}^{-1}$ in all leaves of the vine. In order to favor the pathogen's penetration and infection, the plants were placed in a humid chamber for 24 hours. After 14 days for the first cycle and 7 days for the second cycle, the first symptoms of the disease were observed, when severity assessments were initiated. Five evaluations were carried out every three days. Afterwards, the area under the disease progress curve (AUDPC) was calculated, based on the following Equation 1:

$\mathrm{AUDPC}=\Sigma\left(\mathrm{y}_{\mathrm{i}}+\mathrm{y}_{\mathrm{i}+1}\right) / 2 *\left(\mathrm{t}_{\mathrm{i}+1}-\mathrm{t}_{\mathrm{i}}\right)$,

where:

$\mathrm{n}=$ number of evaluations;

$\mathrm{y}=$ disease severity $(\%)$;

$\mathrm{t}=$ time (days).

\section{Determination of catalase, peroxidase and polyphenoloxidase activity}

Leaf discs with approximately $5 \mathrm{~cm}$ in diameter were randomly collected from 'Isabel Precoce' grapevine plants only in the first cycle, at periods of 6, 48, 72 and 96 hours after treatment application, which were then protected with aluminum foil, cooled on ice and stored in a freezer at $-80^{\circ} \mathrm{C}$, until the preparation of the extracts for biochemical analyzes. For the analyzes, they were weighed and macerated into a mortar with liquid nitrogen, and mechanically homogenized with $1 \%(w / w)$ PVP (polyvinylpyrrolidone) and with $4 \mathrm{~mL}$ of $50 \mathrm{mM}$ potassium phosphate buffer $(\mathrm{pH}$ 7.0) containing $0.1 \mathrm{mM}$ EDTA. The solution was centrifuged at $15,000 \mathrm{~g}$ for $40 \mathrm{~min}$ at $4^{\circ} \mathrm{C}$, and the obtained supernatant was considered an enzymatic extract.

From the enzymatic extract, it was possible to determine:

- Protein content, according to BRADFORD (1976);

- Catalase activity (CAC) (EC 1.11.1.60), according to TOMÁNKOVÁ et al. (2006);

- The activity of the enzyme guaiacol peroxidase (POD) (EC 1.11.1.7), according to LUSSO; PASCHOLATI (1999) and;

- The enzymatic activity of polyphenyl oxidase (PPO) (EC 1.10.3.1), according to DUANGMAL; APENTEN (1999).

\section{Statistical analysis}

All results were submitted to the analysis of variance and, when significant, polynomial regression was carried out, as well as a comparison of the means by the Tukey test at a 5\% of error probability level, using statistical program SISVAR (FERREIRA, 2011).

\section{RESULTS AND DISCUSSION}

\section{In vitro germination of sporangiospores of $P$. viticola}

For the germination of $P$. viticola sporangiospores, there was a quadratic effect as a function of the doses of the $A$. brasiliensis AMS in all evaluation periods. The 10\%,15\% and $20 \%$ doses of the $A$. brasiliensis AMS caused an $80 \%$ reduction in the germination of $P$. viticola sporangiospores in the periods of 4, 6 and 24 hours, and in $12 \mathrm{~h}$, the reduction was $66 \%, 85 \%$, and $91 \%$, respectively. The treatment with $1 \%$ of the suspension, in the 6 and 12 hour periods, induced the germination of the pathogen in $107 \%$ and $101 \%$, respectively, when compared to the control treatment (Figs. $1 \mathrm{E}$ to $1 \mathrm{H}$ ).

Inhibition of $P$. viticola germination is probably due to the fungitoxic phenolic compounds present in the A. brasiliensis mycelial suspension (STANGARLIN et al., 2011; OKE; ASLIM, 2011). Similar results were observed by VIECELLI et al. (2010) using $20 \%$ of the mycelium extract of the mushroom Pycnoporus sanguineus, in which they verified a reduction of up to $70 \%$ in the spores germination of Pseudocercospora griseola, in relation to ASM.

In the present study, treatment with ASM in the $4 \mathrm{~h}$, $6 \mathrm{~h}$, and $12 \mathrm{~h}$ periods did not present different results from the $20 \%$ dose of AMS. Similar results were obtained by MUÑOZ; MORET (2010), who verified the inhibition of the mycelial growth Botrytis cinerea when using acibenzolar-S-methyl in a potato-agar-dextose (PAD) medium. This suggests that, in addition to the inductive effect, ASM can act directly on the pathogen, since it contains sulfur and methyl substance groups that are present in fungicides recommended for mildew control in grape crops (AGROFIT, 2016).

\section{Effect of aqueous mycelial suspension on downy mildew control used on 'Isabel Precoce' grapevines under greenhouse conditions}

The AMS doses of $A$. brasiliensis and acibenzolar-S-methyl, in both cycles of the crop, did not present significant effect on the AUDPC of mildew on 'Isabel Precoce' vines under greenhouse conditions. The mean values observed in the two crop cycles were $344.5 ; 401.3 ; 273.7 ; 339.6 ; 301 ; 360.4$ and 


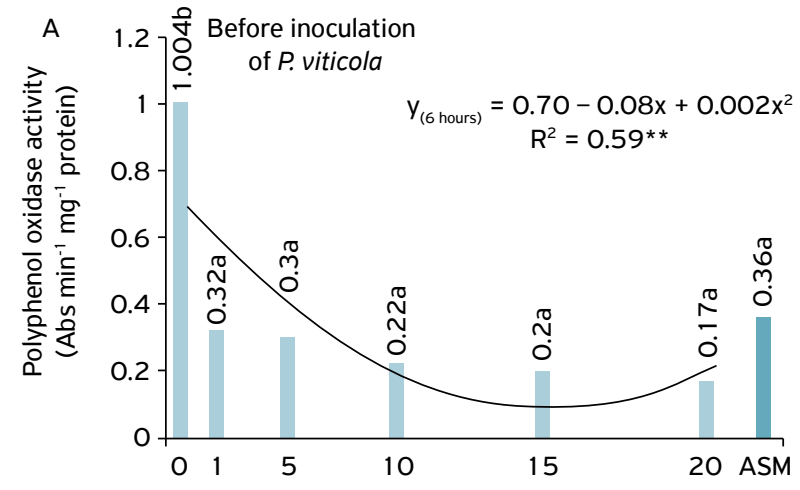

Aqueous mycelial suspension of Agaricus brasiliensis (\%)

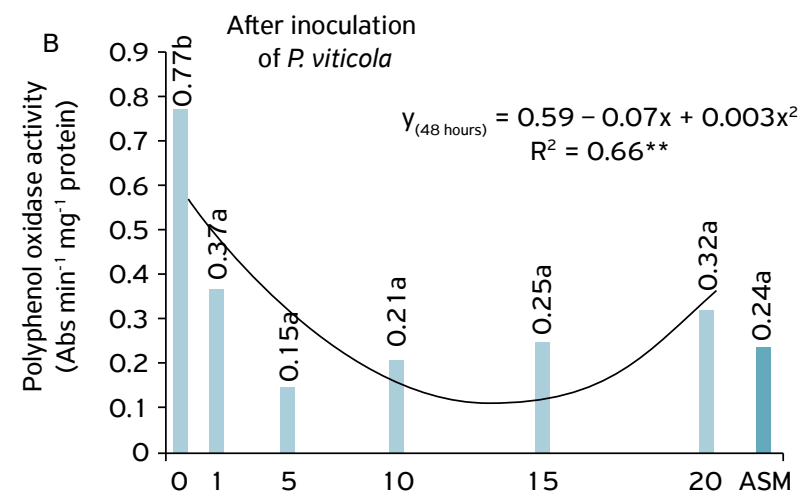

Aqueous mycelial suspension of Agaricus brasiliensis (\%)

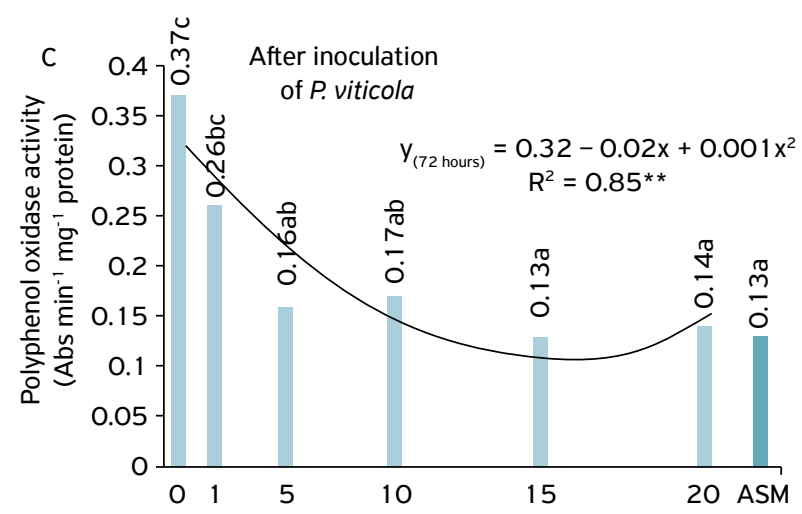

Aqueous mycelial suspension of Agaricus brasiliensis (\%)

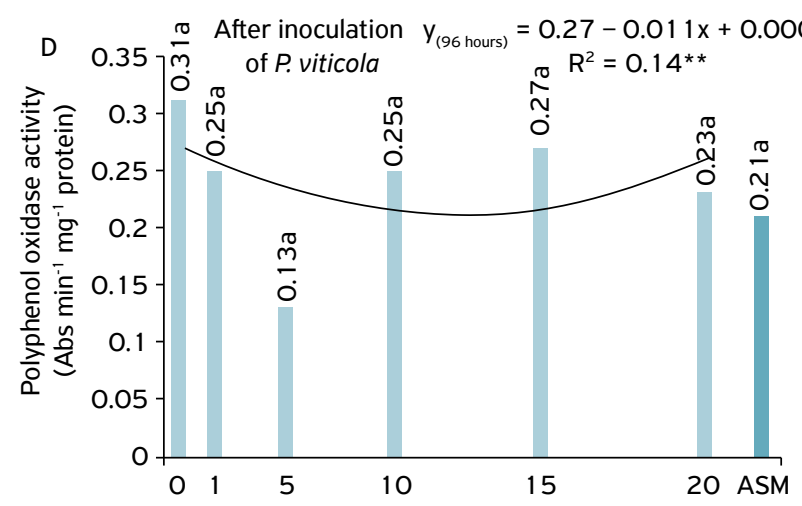

Aqueous mycelial suspension of Agaricus brasiliensis (\%)
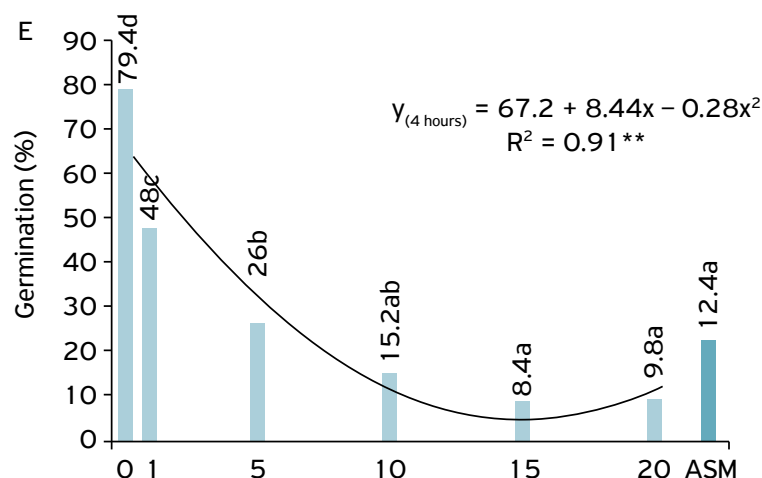

Aqueous mycelial suspension of Agaricus brasiliensis (\%)

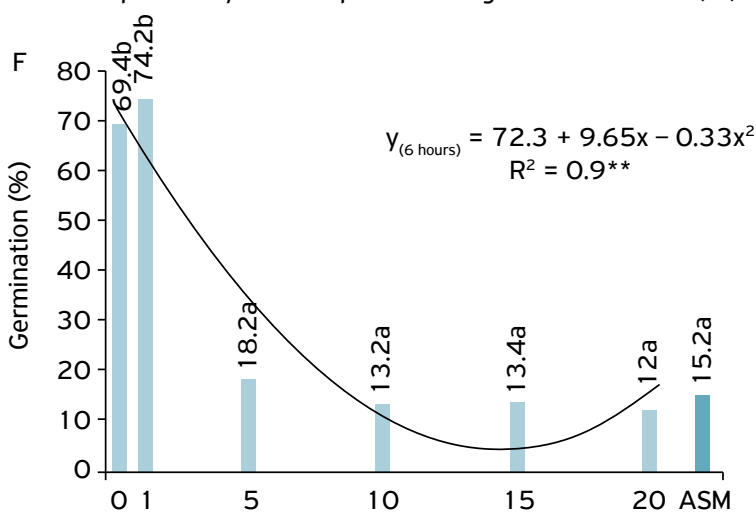

Aqueous mycelial suspension of Agaricus brasiliensis (\%)

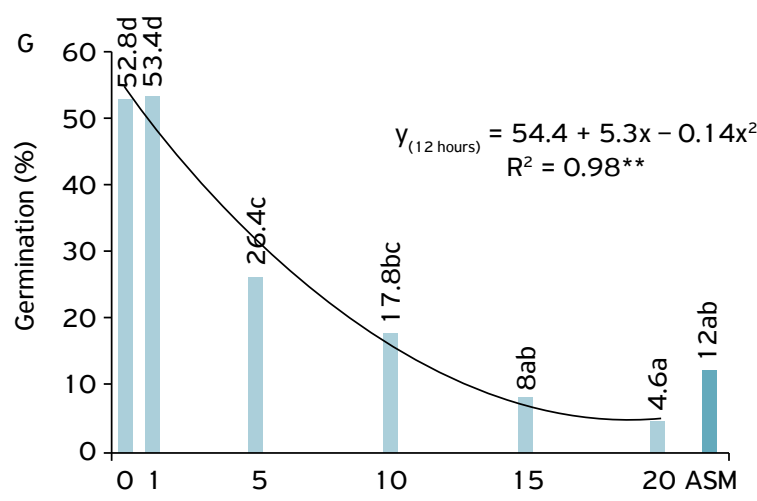

Aqueous mycelial suspension of Agaricus brasiliensis (\%)

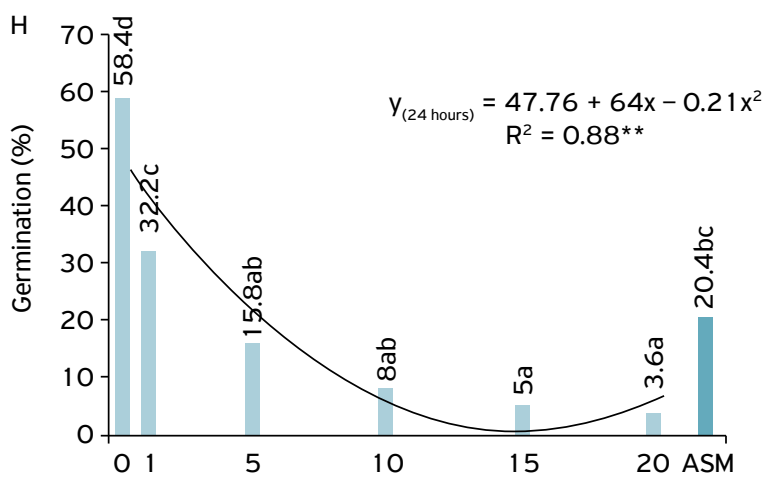

Aqueous mycelial suspension of Agaricus brasiliensis (\%)

Figure 1. Polyphenol oxidase activity (PPO) on vine discs ('Isabel Precoce'), treated with the doses of 1, 5, 10, 15 and 20\% of the aqueous mycelial suspension (AMS) of Agaricus brasiliensis, Acibenzolar-S-methyl $(0.005 \%)$ and absolute control collected in the periods of $6 \mathrm{~h}(\mathrm{~A}), 48 \mathrm{~h}(\mathrm{~B}), 72 \mathrm{~h}(\mathrm{C})$ and $96 \mathrm{~h}(\mathrm{D})$, after the treatments. Germination of Plasmopara viticola sporangia submitted to doses of $1 ; 5 ; 10 ; 15 ; 20 \%$ AMS Agaricus brasiliensis, absolute control and acibenzolar-S-methyl (ASM) (0.005\%). In the periods of: (E) $4 \mathrm{~h}$; (F) $6 \mathrm{~h}$; (G) $12 \mathrm{~h}$ and $(\mathrm{H}) 24 \mathrm{~h}$, after application of the treatments. 


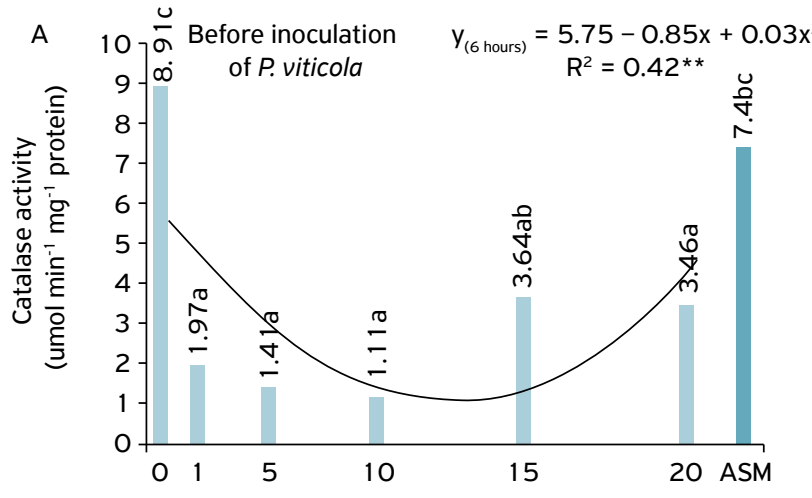

Aqueous mycelial suspension of Agaricus brasiliensis (\%)

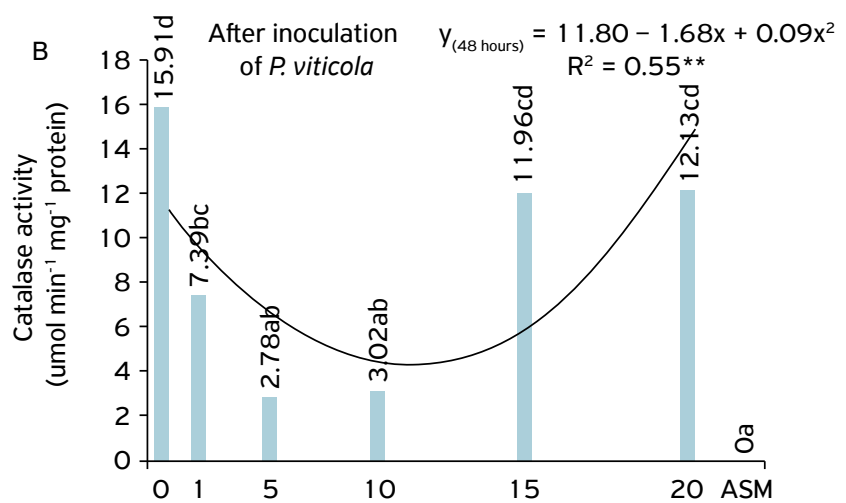

Aqueous mycelial suspension of Agaricus brasiliensis (\%)
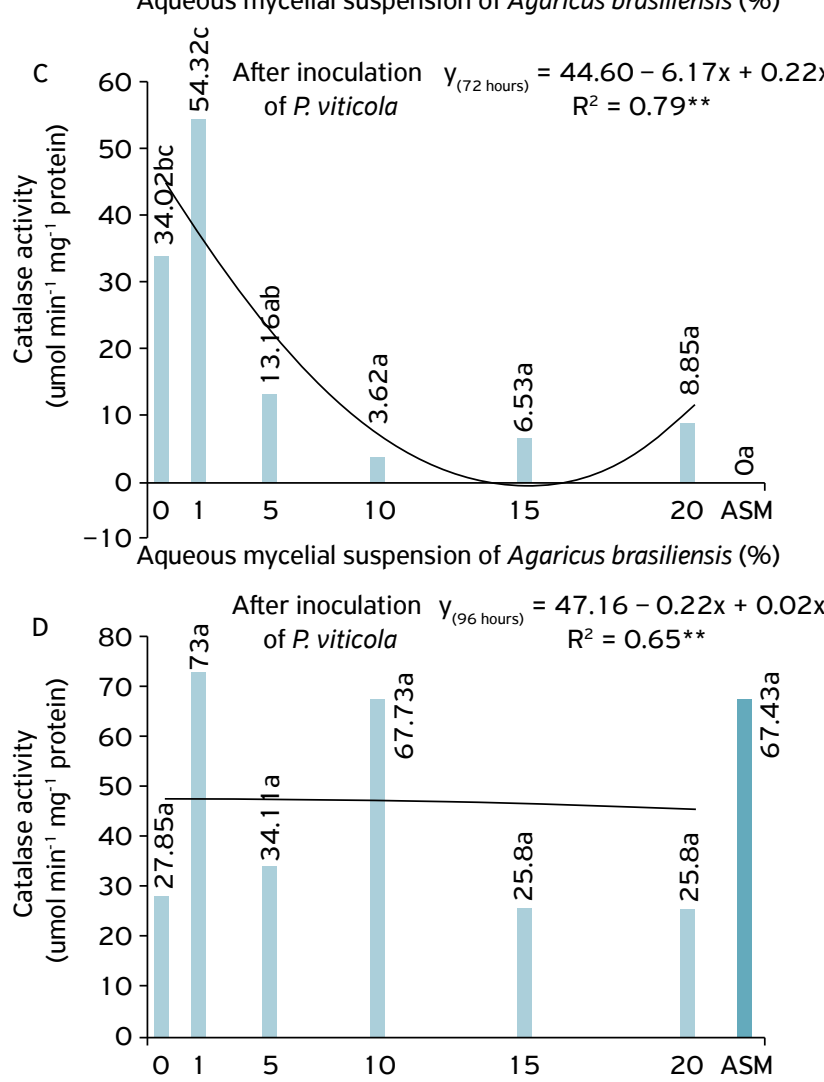

Aqueous mycelial suspension of Agaricus brasiliensis (\%)
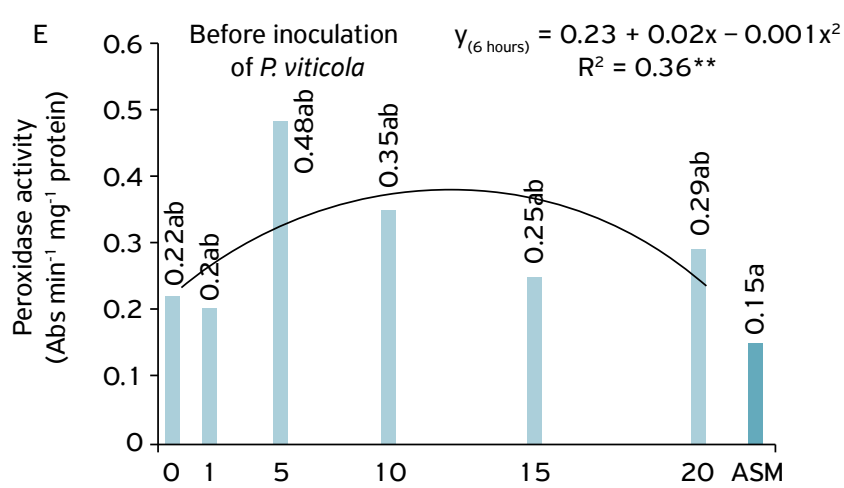

Aqueous mycelial suspension of Agaricus brasiliensis (\%)

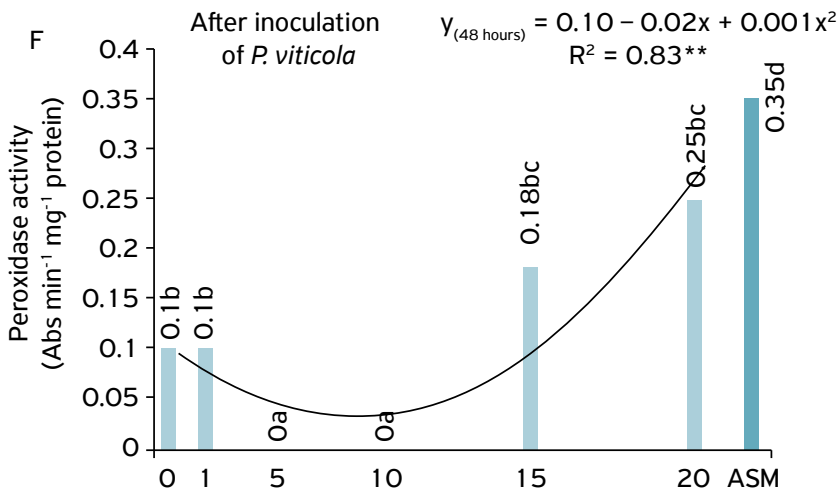

Aqueous mycelial suspension of Agaricus brasiliensis (\%)

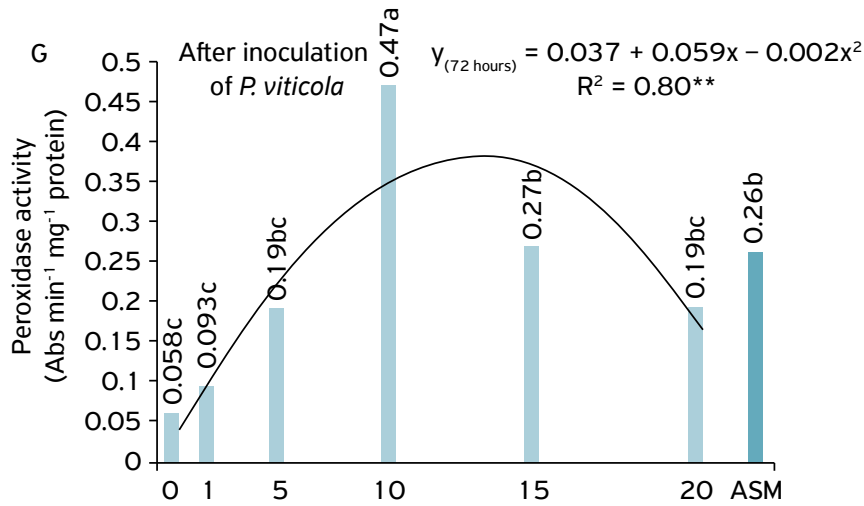

Aqueous mycelial suspension of Agaricus brasiliensis (\%)

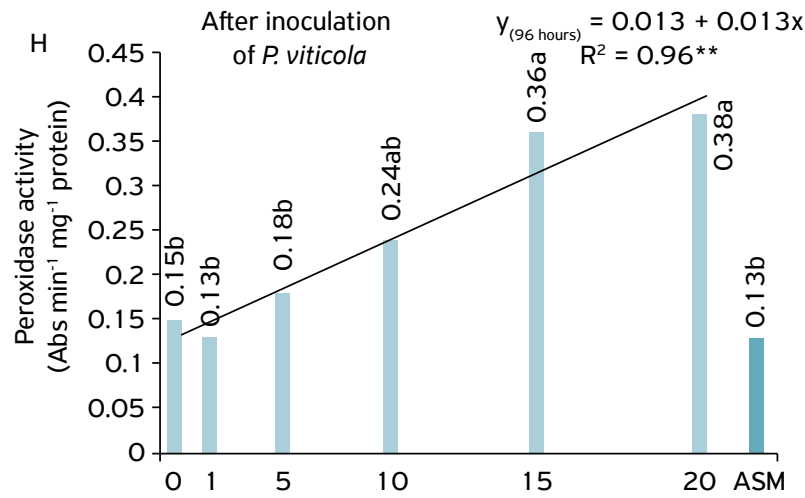

Aqueous mycelial suspension of Agaricus brasiliensis (\%)

Figure 2. Catalase activity (CAT) and peroxidase (POD) in vine discs ('Isabel Precoce'), treated with 1, 5, 10, 15 and $20 \%$ doses of the Agaricus brasiliensis aqueous mycelial suspension, Acibenzolar-S-methyl (0.005\%), and absolute control collected $6 \mathrm{~h}$ (A), $48 \mathrm{~h}(\mathrm{~B}), 72 \mathrm{~h}(\mathrm{C})$ and $96 \mathrm{~h}$ (D) after application of the treatments for CAT, and E, F, G and H for POD activity, in the same periods, after application of the same treatments. Regression analysis performed only for the doses of $A$. brasiliensis AMS. For ASM treatment, averages followed by the same letter do not differ by the Tukey test at $5 \%$ confidence probability. 
271.5 for the treatments of $0,1 \%, 5 \%, 10 \%, 15 \%$ and $20 \%$ of $A$. brasiliensis AMS and ASM, respectively. Activation of the protective effect, according to VIECELLI et al. (2010), will depend on the concentration and the time interval between treatment applications. However, CABRAL et al. (2010), when evaluating the effect of acibenzolar-S-methyl, mananoligosaccharides and citrus bioflavonoids on the control of the watery spot caused by Acidovorax citrulli in melon plants (hybrid AF4945) and Frog Skin type (Nile hybrid), at different times (10 and 15 days after seedling emergence), found that, 10 days after seedling emergence, acibenzolar-S-methyl reduced disease incidence by $88 \%$, and AUDPC by $94 \%$.

\section{Determination of catalase, peroxidase and polyphenol oxidase enzyme activity}

There was a quadratic effect as a function of the $A$. brasiliensis AMS doses for the activity of the catalase enzyme at all evaluated times. The $10 \%$ dose of mushroom AMS inhibited catalase activity in over $80 \%$ at all periods when compared to the control treatment, presenting greater efficiency than the synthetic inductor (ASM), which, in 6 and 48 hours, reduced the activity of this enzyme in $11 \%$ and $24 \%$, respectively (Figs. $1 \mathrm{~A}$ and $1 \mathrm{~B}$ ).

Catalase has the main function of degrading hydrogen peroxide $\left(\mathrm{H}_{2} \mathrm{O}_{2}\right)$. The low activity of this enzyme possibly results in high concentration of $\mathrm{H}_{2} \mathrm{O}_{2}$, which is a reactive oxygen species that can act as secondary messenger in the induction of genes related to pathogenicity, as well as strengthening the plant's cell wall through cross-links with structural proteins or the lipid peroxidation of the plasma membrane, thus increasing its integrity and inducing a certain resistance of these plants. However, it was not efficient to control vine mildew (TORRES et al., 2006; SOARES; MACHADO, 2007; VELLOSILLO et al., 2010).

In $96 \mathrm{~h}$, it was observed that doses of both AMS and ASM did not interfere with the catalase's enzymatic activity, because oxidative explosion-related enzymes often present a very rapid response, occurring within seconds, minutes and hours after the application of the elicitor treatment or addition of the pathogen (HEISER; OBWALD, 2008) (Fig. 2D). This may be related to the high activity of POD, which presented a stimulus with the increase of the dose of A. brasiliensis AMS (Figs. 1E to $1 \mathrm{H}$ ) in the same period. POD probably consumes the $\mathrm{H}_{2} \mathrm{O}_{2}$ present in the cell, which, in the previous period for oxygenation, and eventual polymerization of hydroxycinnamic alcohol, gives rise to lignin, which acts as a physical barrier to pathogen penetration (STANGARLIN; LEITE, 2008).
In addition, POD and PPO can oxidize the phenolic compounds, mainly chlorogenic acid, that are found in this classification, which originates quinones that are highly toxic to pathogens (BARROS et al., 2010). Both can compete for the same substrate. According to the results obtained, there was inhibition of PPO activity by POD (Figs. 2A to 2D).

Similar results were observed by SILVA et al. (2007), who reported that tomato plants treated with extract of basidiocarp of A. blazei and ASM inoculated with the bacterium Ralstonia solanacearum showed increased POD activity and PPO reduction. SILVA et al. (2008), when treating eggplant plants with basidiocarp extract of $A$. blazei and ASM, obtained an increase in POD activity. DI PIERO et al. (2006) found that cucumber plants treated with the aqueous extract of the $L$. edodes mushroom basidiocarp caused a reduction in anthracnose severity and increased peroxidase activity in leaves.

Most of the work with the $A$. brasiliensis mushroom is carried out with the extract made from the basidiocarp. In this study, mycelium extract was used, with a moisture content of $94 \%$, in which the concentration of active principles can be smaller, which probably contributed to the absence of mildew's AUDPC reduction. Another factor to be considered is that $P$. viticola is part of the group of biotrophic pathogens, which have a specialized structure such as haustory, which, in addition to removing nutrients from host cells, can also produce and transport effectors for these cells. These effectors, in incompatible interactions, manipulate the metabolism of host cells and hinder the performance of the host plant'a defense system (AMORIM; PASCHOLATI, 2011).

\section{CONCLUSIONS}

The Agaricus brasiliensis aqueous mycelial suspension and acibenzolar-S-methyl inhibited sporangiospore germination of $P$. viticola.

The severity of the mildew was not reduced with application of the mycelial suspension of A. brasiliensis and acibenzolar-S-methyl.

The $A$. brasiliensis aqueous mycelial suspension and acibenzolar-S-methyl induced the activity of the catalase, peroxidase and polyphenol oxidase enzymes.

\section{ACKNOWLEDGMENTS}

The authors would like to thank the Coordination of Improvement of Higher Level Personnel (CAPES) for granting the scholarship to the first author. 

REFERENCES

AGROFIT Sistema de Agrotóxicos Fitossanitários. Consulta de Praga/Doença. Available from: <http://extranet.agricultura.gov.br/ agrofit_cons/principal_agrofit_cons> Accessed on: Oct. 12016.

AMORIM, L.; KUNIYUKI, H. Doenças da Videira. In: . Manual de Fitopatologia. Doenças das Plantas Cultivadas. 4.ed. São Paulo: Agronômica Ceres, 2005. Cap. 70, p.639-651.

AMORIM, L.; PASCHOLATI, S. Ciclo das relações patógeno-hospedeiro. In:__. Manual de Fitopatologia. Princípios e conceitos. 4.ed. São Paulo: Agronômica Ceres, 2011.p.639-651.

ARRUDA, R.S.; MESQUINI, R.M.; SCHWAN-ESTRADA, K.R.F.; NASCIMENTO, J.F. Efeito de extratos de cogumelos na indução de fitoalexinas e no controle de oídio da soja em casa de vegetação. Bioscience Journal, Uberlândia, v.28, p.164-172, 2012.

BARROS, F.C.; SAGATA, É.; FERREIRA, L.C.C.; JULIATI, F.C. Indução de resistência em plantas contra fitopatógenos. Bioscience Journal, Uberlândia, v.26, p.231-239, 2010.

BRADFORD, M.M. A rapid and sensitive method for the quantitation of microgram quantities of protein utilizing the principle of protein-dye binding. Analytical Biochemistry, Georgia, v.72, p.248-254, 1976.

CABRAL, C.P.; GAMA, M.A.S.; ALEXANDRE, E.R.; MARIANO, R.L.R.; SILVEIRA, Z.B. Efeito de acibenzolar-S-metil, manamoligossacarídeo e bioflavonóides cítricos no controle da mancha-aquosa e no crescimento do meloieiro. Tropical Plant Pathology, Brasília, v.35, n.2, p. $119-123,2010$.

CAMARGO, U.A.; MAIA, J.D.G.; RITSCHEL, P. Embrapa uva e vinho novas culturas brasileiras de uva. Bento Gonçalves: Embrapa, 2010. 64p.

DALLA SANTA, H.S.; RUBEL, F.; VITOLA, F.; TARARTHUCH, A.L.; LIMA FILHO, J.H.C.; FIGUEREDO, B.C.; DALLA SANTA, O.R.; RAYMUNDO, M.S.; HABU, S.; SOCCOL, C.R. Kidney function indices in mice after long intake of Agaricus brasiliensis mycelia (=Agaricus blazei, Agaricus subrufescens) produced by solid state cultivation. On line biological science, v.9, n.2, p.21-28, 2009.

DI PEIRO, R.M.; WULFF, N.A.; PASCHOLATI, S.F. Partial purification of elicitors from Lentinula edodes basidiocarps protecting cucumber seedlings against Colletotrichum lagenarium. Brazillian Journal of Microbiology, São Paulo, v.37, p.175-180, 2006.

DUANGMAL, K.; APENTEN, R.K.O. A comparative estudy of poliphenoloxidases from taro (Colocasia esculenta) e potato (Solanum tuberosum var. Romano). Food Chemistry, v.64, n.1, p.351-359, 1999.

FERREIRA, D.F. SISVAR: a computer statistical analysis system. Ciência e Agrotecnologia, Lavras, v. 35, n. 6, p.1039-1042, 2011.

FIORI-TUTIDA, A.C.G.; SCHWAN-ESTRADA, K.R.F.; STANGARLIN, J.R.; PASCHOLATI, S.F. Extracts of Lentinula edodes and Agaricus blazei on Bipolaris sorokiniana and Puccinia recondita f.sp. tritici, in vitro. Summa Phytopathologica, Botucatu, v.33, n.3, p.113-118, 2007.

HEISER, I.; OBWALD, W.F. Formação e função das espécies reativas de oxigênio nas interações planta-patógeno. In:__. Interação planta-patógeno: Fisiologia, Bioquímica e Biologia Molecular, Piracicaba, 2008, p. 249-283.

JERMINI, M.M.; BLAISE, P.; GESSLER, C. Response of 'Merlot' (Vitis vinifera) grapevine to desfoliation caused by downy mildew (Plasmopara viticola) during the following growing season. Vitis, Zürich, v.49, n.4, p.161-166, 2010.

LUSSO, M.F.G.; PASCHOLATI, S.F. Activity and isoenzymatic pattern of soluble peroxidases in maize tissues after mechanical injury or fungal inoculation. Summa phytopathologica, Botucatu, v.25, p.244-249, 1999.

OKE, F.; ASLIM, B. Protective effect of two edible mushrooms against oxidative cell damage and their phenolic composition. Food chemistry, v.128, n.3, p.613-619, 2011.

PICCININ, E.; DI PEIRO, R.M.; PASCHOLATI, S.F. “Shiitake” (Lentinula edodes) mushroom resuces growth of plant pathogens and leaf spot severity in sorghum. Summa phytopathologica, Botucatu, v.36, p.68-72, 2010.

SCHWAN-ESTRADA, K.R.F.; STANGARLIN, J.R.; KUHN, O.J.; BONALDO, S.M. Uso de extratos vegetais e cogumelos na indução de resistência a patógenos. In: ___. Indução de resistência em plantas a patógenos. 2012. Cap.2, p.9-28.

SILVA, R.F.; PASCHOLATI, S.F.; BEDENDO, I.P. Indução de resistência em tomateiro por extratos aquosos de Lentinula edodes e Agaricus blazei contra Ralstonia solanacearum. Fitopatologica brasileira, Brasília, v.32, n.3, p.189-196, 2007. http://dx.doi.org/10.1590/ so $100-41582007000300002$

SILVA, R.F.; PASCHOLATI, S.F.; BEDENDO, I.P. Indução de resistência em plantas de berinjela por Lentinula edodes e Agaricus brasiliensis contra Ralstonia solanacearum: aspectos bioquímicos e biomassa vegetal. Summa phytopathologica, Botucatu, v.34, n.3, p.137-144, 2008.

SOARES, A.C.F.; PEREZ, J.O.; SOUZA, C.S.; GARRIDO, M.S.; ALMEIDA, N.S. Eficiência de acibenzolar-s-metil na proteção de plantas de inhame à Curvularia eragrostides. Revista Caatinga, Mossoró, v.21, n.1, p.147-151, 2008.

SOARES, A.M.; MACHADO, O.L.T. Defesa de plantas: sinalização química e espécies reativas de oxigênio. Revista Trópica- Ciências Agrárias e Biológicas, Chapadinha, v.1, n.1, p.9-19, 2007.

STANGARLIN, J.R.; TOLEDO, M.V.; PORTZ, R.L.; SCHWAN-ESTRADA, K.R.F.; PASCHOLATI, S.F. A defesa vegetal contra fitopatógenos. Scientia Agraria Paranaensis, Marechal Candido Rondon, v.10, n.1, p.18-46, 2011 . http://dx.doi. org/10.1818/sap.v10i1.5268 
STANGARLIN, J.R.; LEITE, B. Alterações fisiológicas na suscetibilidade. In: . Interação planta- patógenos: fisiologia, bioquímica e biologia molecular, 2008. Cap. 5, p.177-284.

TOMÁNKOVÁ, K.; LUHOVÁ, L.; PETØIVALSKÝ, M.; PEĖ, P.; LEBEDA, A. Biochemical aspects of reactive oxygen species formation in the interaction between Lycopersicon spp. and Oidium neolycopersici. Physiological and Molecular Plant Pathology, v.68, p.22-32, 2006.

TORRES, M.A.; JONES, J.D.G.; DANGL, J.L. Reative oxygen species signaling in response to pathogens. Plant Physiology, v. 141, n.2, p.373-378, 2006. http://dx.doi.org/10.1 104/pp.106.079467

TROUVELOT, S.; VANIER, A.L.; ALLÈGRE, M.; MERCIER, L.; BAILILIEUL, F.; ARNOULD, C.; GIANINAZZI-PEARSON, V.; KLARZYNSKI, O.; JOUBERT, J.M.; PIGIN, A.; DAIRE, X. $\beta-1,3$
Glucan sulfate induces resistence in grapevine against Plasmopara viticola through priming of defenses responses, including HR-like cell death. Molecular plant-microbe interactions, v.21, n.2, p.232-243, 2008. http://dx.doi.org/10.1094/ MPMI-21-2-0232

VELLOSOLLI, T.; VICCENTE, J.; KULASEKARAN, S.; HAMBERG, M.; CASTRESANA, C. Emerging complexity in reactive oxygen species production and signaling during the response of plants to pathogens. Plant Physiology, v.154, n.2, p.444-448, 2010. http://dx.doi.org/10.1104/pp.110.161273

VIECELLI, C.A.; STANGARLIN, J.R.; KUHN, O.J.; SCHWAN-ESTRADA, K.R.F. Resistance induction in bean plants against angular leaf spot by extracts from Pycnoporus sanguineus mycilium. Summa Phytopathologica, Botucatu, v.36, n.1, p.73-80, 2010. 